\title{
Fenomena Bullwhip Effect pada Supply Chain dan Struktur Tata Kelola Perguruan Tinggi
}

\author{
Farham HM. Saleh \\ Universitas Islam Indonesia Yogyakarta \\ farham@ti.uii.ac.id
}

Bullwhip effect is the phenomenon in which information on demand is distorted while moving upstream along supply chain. This causes a variance of demand to be amplified. Generally, researches about the bullwhip effect are conducted in supply chain of goods industries, and not in that of service industries. To what extent is the bullwhip effect possible in service industries, especially in university governance? This research has been conducted to analyze whether the bullwhip effect may happen in university governance. This research has revealed that subject to a specific condition, a similar bullwhip effect phenomenon may happen in university governance.

Keywords: bullwhip effect, special condition, university governance

\section{Pendahuluan}

$\mathrm{M}$ anajemen rantai pasok (Supply Chain Management, SCM) merupakan bahasan standar pada perguruan-perguruan tinggi penyelenggara Business Administration (Master Business Administration, MBA) pada beberapa dekade terakhir [Dhahri dan Chabchoub, 2007]. Hal ini menunjukkan bahwa permasalahan-permasalahan dalam lingkup business supply chain cukup mempengaruhi performansi perusahaan yang terlibat dalam jaringan supply chain tersebut.

Supply Chain merupakan mata rantai bisnis mulai dari konsumen (customer) sampai ke para suplier (suppliers) bahan baku. Supply chain dapat merupakan suatu mata rantai bisnis yang paling sederhana yaitu yang terdiri dari satu pengecer (retailer), satu produsen (manufacturer) dan satu suplier (supplier). Namun juga dapat merupakan suatu mata rantai bisnis yang kompleks yaitu yang terdiri dari banyak pengecer (retailers), banyak agen atau grosir (wholesalers), banyak produsen (manufacturers) dan banyak penyedia bahan baku (suppliers).

Dalam supply chain, mata rantai pemenuhan demand terjadi atau akan turun (downstream) dari suppliers bahan baku sampai ke pengecer (retailers) sedangkan dari konsumen secara upsteam sampai ke suplier akan terdapat aliran informasi tentang jumlah demand yang dibutuhkan pada masing-masing chain dalam supply chain. Aliran informasi dari konsumen dimungkinkan terjadi distorsi (distorsi informasi) karena hanya retailer yang berhadapan langsung dengan konsumen. Artinya bahwa yang paling mengetahui kuantitas kebutuhan riil konsumen adalah retailer, sedangkan agen, produsen dan suplier bahan baku tidak. Selain itu juga 
Fenomena Bullwhip Effect pada...; Farham HM. Saleh

karena berbagai faktor yang dipertimbangkan ketika melakukan pengambilan keputusan, baik faktor internal maupun faktor eksternal. Distorsi informasi upstream akan semakin besar ketika melewati setiap chain sampai pada sisi suppliers dengan semakin panjangnya mata rantai dalam business supply chain. Distorsi informasi upstream sepanjang supply chain dinamakan Bullwhip Effect.

Bullwhip Effect merupakan fenomena bertambahnya variasi kuantitas demand ketika bergerak upstream sepanjang supply chain (variasi merupakan penyimpangan dari harga rata-rata). Distorsi informasi sepanjang supply chain dimungkinkan bertambah dengan bertambah kompleksnya mata rantai bisnis dalam supply chain. Distorsi informasi pada setiap chain sepanjang supply chain akan berdampak pada keputusan tentang jumlah pemesanan (order quantity), kebijakan persediaan (inventory policy) dan tentu saja biaya (cost).

Bullwhip effect merupakan salah satu hal dalam supply chain yang banyak menarik minat peneliti dalam beberapa decade terakhir (Luong, 2007). Menurut Luong (2007) serta Luong dan Phien (2007), bullwhip effect mulai menjadi perhatian para peneliti pada akhir tahun 1950-an. Lebih lanjut dikemukakan, bahwa yang mempelopori melakukan investigasi tentang bullwhip effect adalah Forrester [1958] yang kemudian dilanjutkan oleh beberapa peneliti yang disebutkan antara lain Blanchard (1983), Blinder (1982, 1986) dan Kahn (1987). Para peneliti pionir tersebut telah mencatat keberadaan atau eksistensi dari bullwhip effect pada supply chain.

Beberapa penelitian tentang bullwhip effect dalam dua tahun terakhir dilakukan antara lain oleh Luong (2007), Luong dan
Phien (2007), Ozelkan dan Cakanyildirim (2007), Dhahri dan Chabchoub (2007), Hsieh, Chen dan Shen (2007), Agrawal, Sengupta dan Shanker (2007), Ouyang (2007) serta Ouyang dan Daganzo [2008]. Lingkup penelitian yang mereka lakukan adalah formulasi pengukuran bullwhip effect (BE) untuk demand process autoregresi orde 1 (Luong, 2007) yang biasa ditulis AR(1) dan untuk demand process autoregresi orde yang lebih tinggi (Luong dan Phien, 2007), yang biasa ditulis $\operatorname{AR}(p)$. Dhahri dan Chabchoub (2007) mengembangkan model nonlinier goal programming dengan basis parameter ARIMA untuk mengkuatifisir BE; Hsieh, Chen dan Shen (2007) mengembangkan model untuk mengestimasi bootstrap confidence interval dari BE serta Ouyang dan Daganzo (2008) mengembangkan model robust test untuk BE pada kondisi stocastic dynamics.

Metode identifikasi terjadi tidaknya BE dan seberapa besarnya BE, para peneliti sepakat menggunakan dasar rasio deviasi rata-rata kuantitas demand pada setiap chain yaitu rasio deviasi rata-rata kuantitas demand pada pengecer terhadap deviasi rata-rata kuantitas demand pada konsumen atau rasio deviasi rata-rata kuantitas demand pada agen atau grosir terhadap deviasi ratarata kuantitas demand pada pengecer, dan seterusnya sampai ke ujung supply chain yaitu supplier.

Untuk mengidentifikasi dan mengukur BE, Luong (2007) serta Luong dan Phien (2007) menggunakan rasio variansi (variansi adalah kuadrat dari standar deviasi), sedangkan Fransoo dan Wouters (2003) serta Zabidi (2003) menggunakan rasio koefisien variansi. Luong [2007] mengemukakan, bahwa tidak terdapat perbedaan yang signifikan pada kedua metode pengukuran tersebut. 
UNISIA, Vol. XXXI No. 69 September 2008

Selain dari model pengukuran BE, penelitian dilakukan juga terhadap faktorfaktor yang mempengaruhi BE. Agrawal, Sengupta dan Shanker (2007) serta Ouyang (2007) meneliti pengaruh dari information sharing terhadap BE. Dari survey yang dilakukan oleh Luong (2007) dikemukakan bahwa beberapa peneliti yang memodelkan pengaruh metode peramalan terhadap $B E$ antara lain Chen et. Al. (2000a,b) dengan metode peramalan exponential smothing, Baganda dan Cohen (2005) dengan teknik peramalan multi-step dan Zhang (2004) dengan metode peramalan autoregresi orde 1 atau $A R(1)$. Lingkup penelitian lain pada $\mathrm{BE}$ adalah pengaruh lead time terhadap $\mathrm{BE}$ dilakukan antara lain oleh Zhang (2004) dalam Luong (2007) dan Luong (2007) dan tingkat eselon supply chain dilakukan oleh Chen et.al (2004) untuk simple supply chain dan Zhang (2004) untuk two-echelon supply chain. Lingkup penelitian yang dikemukakan di atas menunjukkan bahwa begitu banyak faktor yang mempengaruhi $\mathrm{BE}$.

\section{Kajian Pustaka}

\section{Penyebab Bullwhip Effect}

Beberapa peneliti antara lain Luong (2007), Luong dan Phien (2007) serta Ozelkan dan Cakanyildirin (2007) mengemukakan bahwa terdapat lima faktor utama sebagai penyebab BE yaitu peramalan permintaan (demand forecasting), tenggang waktu pemenuhan pesanan (non-zero lead time), ukuran pemesanan (order batching), kekurangan suplai atau persediaan (supply shortages), dan fluktuasi harga (price fluctuations).

Pada bentuk supply chain yang paling sederhana yaitu yang masing-masing terdiri dari satu pengecer, satu produsen dan satu suplier bahan baku, maka kesalahan informasi yang dilakukan oleh pengecer dapat menyebabkan ketidaktepatan kuantitas pemesanan yang dilakukan pada produsen dan kesalahan peramalan yang dilakukan oleh produsen akan berdampak pada terjadinya kesalahan pada jumlah produk yang harus diproduksi dan disediakan serta jumlah bahan baku yang harus dipesan dari suplier. Variasi jumlah produk yang disediakan oleh pengecer maupun yang diproduksi oleh produsen, baik berupa kekurangan maupun kelebihan jumlah persediaan produk tersebut dapat menimbulkan BE.

Banyak produk manufaktur yang memerlukan waktu pemesanan (lead time) terlebih dahulu sebelum produk tersebut dapat digunakan atau diperdagangkan. Lama waktu pemesanan produk sangat bervariasi, bergantung pada jenis produk dan berbagai faktor lainnya. Misalnya mobil, untuk tipe tertentu dapat langsung dibeli di agen atau pengecer tetapi untuk tipe yang lain dengan merk yang sama, memerlukan waktu berbulan-bulan untuk dapat memilikinya. Adanya tenggang waktu pemesanan menyebabkan agen atau pengecer melakukan perkiraan atau peramalan untuk kebutuhan di masa datang. Peramalan yang dilakukan dapat terjadi kesalahan, dapat terjadi kelebihan maupun kekurangan persediaan sehingga dapat menyebabkan terjadinya BE.

Dalam melakukan pemesanan produk misalnya dari agen pada produsen, kuantitas produk yang dipesan (order batching) dapat bervariasi bergantung pada perkiraan akan permintaan dari pengecer atau terjadi fluktuasi kuantitas pemesanan. Kadangkadang juga terjadi pada waktu tertentu pesan tetapi pada waktu berikutnya tidak pesan. Hal seperti ini jelas menimbulkan ketidakpastian, yang berdampak pada terjadinya kelebihan atau kekurangan 
Fenomena Bullwhip Effect pada...; Farham HM. Saleh

persediaan. Selain itu untuk produk tertentu, harus dipesan dalam satuan batch tertentu, misalnya lusin, kodi atau kontainer. Karena harus dipesan dalam satuan batch tertentu, maka jumlah unitnya dapat terjadi kekurangan ataupun kelebihan sehingga jelas bahwa order batching dapat menimbulkan BE.

Dua terakhir penyebab utama terjadinya BE adalah kekurangan suplai atau persediaan dan fluktuasi harga. Kekurangan suplai atau persediaan telah secara implisit dijelaskan pada tiga faktor sebelumnya. Fluktuasi harga suatu produk dapat berdampak pada keputusan tentang jumlah produk yang harus disediakan untuk diperdagangkan karena dari sisi konsumen fluktuasi harga dapat mempengaruhi keputusan membeli, menunda membeli atau tidak membeli. Ketidakpastian kuantitas produk yang disediakan sebagaimana dijelaskan sebelumnya dapat berdampak pada munculnya $\mathrm{BE}$.

\section{Struktur Tata Kelola Perguruan Tinggi}

Di luar yayasan, umumnya struktur tata kelola perguruan tinggi (PT) terdiri dari tingkat universitas, tingkat fakultas, tingkat jurusan atau program studi (prodi) dan tingkat operasional administratif. Pada tingkat universitas direpresentasikan Rektor dengan wakilnya, pada tingkat fakultas diwakili Dekan dengan wakilnya, pada tingkat jurusan atau prodi diwakili oleh Ketua jurusan atau Ketua prodi dan pada tingkat operasional adminisratif diwakili oleh bagian atau divisi. Namun satu unit lagi pada tingkat operasioanal yang berhadapan langsung dengan mahasiswa (konsumen) yaitu dosen.

Dalam struktur tata kelola PT, aliran tugas atau pelaksanaan program akan mengalir downsteam dari Rektor sampai ke bagian atau divisi sedangkan aliran informasi tentang hasil pelaksanaan program akan mengalir upstream dari bagian atau divisi sampai ke Rektor. Pada tingkat bagian atau divisi dilaksanakan program-program yang bersifat rutin administratif seperti adiministrasi perkuliahan, pembuatan jadwal kuliah, dokumentasi keaktifan mengajar dosen dan ketepatan waktu penyerahan nilai oleh dosen, yang secara umum merupakan pelayanan langsung pada konsumen. Semua kegiatan tersebut untuk mendukung program yang dilaksanakan oleh jurusan atau prodi dan fakultas. Hasil dari semua kegiatan tersebut dilaporkan atau diiformasikan ke jurusan atau prodi dan fakultas.

Pada tingkat jurusan atau prodi dilaksanakan program-program yang bersifat teknis dan strategis untuk lingkup jurusan atau prodi. Program yang bersifat teknis misalnya adiministrasi ujian pendadaran mahasiswa, pembimbing kerja praktek dan penelitian, sedangkan program yang bersifat strategis antara lain program peningkatan kapabilitas profesionalisme dosen sesuai dengan Tri Dharma PT, pengembangan soft skill dan keahlian mahasiswa (konsumen) serta mempromosikan jurusan atau prodi. Semua kegiatan tersebut dilaporkan atau diinformasikan ke fakultas.

Pada tingkat fakultas dilaksanakan program-program yang bersifat strategis untuk lingkup fakultas yang merupakan breakdown dari program strategis di tingkat universitas. Program-program strategis tersebut antara lain melaksanakan kegiatan koordinasi pelaksanaan program seluruh jurusan dalam lingkup fakultas seperti seminar bersama, mensinergikan penggunaan fasilitas-fasilitas fakultas oleh jurusanjurusan dan menyusun program strategis atau rencana strategis tingkat fakultas. Semua pelaksanakan program tesebut dilaporkan dan diinformasikan ke tingkat universitas. 
UNISIA, Vol. XXXI No. 69 September 2008

Pada tingkat universitas yang merupakan tingkat tertinggi dari suatu PT, dilaksanakan program-program yang bersifat strategis bagi PT tersebut. Program-program strategis tersebut antara lain melaksanakan program studi lanjut dosen, melaksanakan program penjaminan mutu, dan melaksanakan program kerjasama dengan institusi lain seperti pemerintah, lembaga-lembaga pemerintah, industri dan perguruan tinggi lain baik di dalam maupun di luar negeri. Selain melaksanakan program-program strategis tersebut, tingkat universitas juga melaksanakan program teknis taktis yaitu penerimaan mahasiswa baru.

Uraian pelaksanaan program yang mengalir downstream dan aliran informasi hasil pelaksanaan program upstream pada PT tersebut di atas, terlihat sama dengan yang terjadi pada supply chain industri manufaktur. Apakah dengan demikian pada struktur tata kelola PT yang merupakan industri jasa dapat terjadi BE. Jawaban pertanyaan tersebut akan dikemukakan pada bagian selanjutnya. Namun demikian sebelum menjawab pertanyaan tersebut, perlu diperjelas terlebih dahulu fokus bahasan.

Secara umum setiap PT mempunyai dua macam pelanggan yaitu pelanggan internal dan pelanggan eksternal. Pelanggan internal adalah mahasiswa sedangkan pelanggan eksternal antara lain calon mahasiswa, industri-industri, institusiinstitusi pemerintah maupun swasta, dan PT lain. Pendefinisian pelanggan tersebut digunakan untuk pembahasan dalam makalah ini dan untuk menjawab pertanyaan di atas, analisis dilakukan hanya untuk pelanggan internal dan berangkat kinerja dosen.

\section{Pembahasan}

Bullwhip effect yang terjadi pada business supply chain yang dikaji oleh para peneliti sebagaimana dikemukakan pada bagian awal tulisan ini adalah business suppy chain dimana pada setiap chain merupakan pertemuan antara dua perusahaan dengan kepemilikan yang berbeda. Artinya bahwa hubungan yang terjadi antara dua atau lebih perusahaan pada setiap chain dalam supply chain merupakan hubungan bisnis. Hal ini menjadi penting untuk ditegaskan mengingat bahwa jika business supply chain berada dalam satu perusahaan, maka keputusan pada seluruh chain dapat dikendalikan oleh satu tim pengambilan keputusan sehingga sangat sulit bahkan tidak mungkin terjadi BE. Justru yang ingin dianalisis adalah apakah mungkin terjadi BE pada PT yang merupakan industri jasa dengan satu kepemilikan.

Pada business supply chain industri manufaktur yang outputnya tangible (dapat dipegang), keputusan tentang berapa jumlah produk atau bahan baku yang harus disediakan terukur dalam satuan yang jelas, misalnya unit, lusin atau kodi. Oleh karena itu, dengan menggunakan rumus-rumus baku akan dengan mudah dapat dihitung besarnya rata-rata, standar deviasi, variansi dan koefisien variansi, yang dapat digunakan untuk mengidentifikasi dan mengukur BE. Sedangkan pada industri jasa khususnya PT yang menghasilkan jasa pelayanan yang salah satu sifatnya adalah intangible [Gaspersz, 1997] dan merupakan industri dengan satu kepemilikan sangat sulit untuk mengukur BE dan bahkan mungkin BE tidak akan terjadi. Namun demikian ada hal-hal tertentu dalam pengelolaan PT yang dapat dianalisis menggunakan fenomena BE.

Telah dikemukakan di atas bahwa pada struktur tata kelola PT secara downstream 
Fenomena Bullwhip Effect pada...; Farham HM. Saleh

terdapat aliran bentuk dan pelaksanaan program dan secara upstream terdapat aliran informasi tentang hasil pelaksanaan program. Unit yang berhadapan langsung dengan konsumen adalah bagian atau divisi dan dosen. Analisis yang dilakukan dalam makalah ini dilakukan berdasarkan kinerja dosen.

Kinerja dosen merupakan salah satu faktor penting bagi kinerja keseluruhan suatu PT. Aktivitas dosen yang berhadapan langsung dengan mahasiswa adalah pendidikan dan pengajaran yang merupakan salah satu komponen dari Tri Dharma PT. Kinerja dari dosen dapat dinilai antara lain dari penguasaan terhadap materi mata kuliah yang diajarkan (dengan salah satu indikator kesesuaian materi dengan SAP, satuan acara perkuliahan), kemampuan mentranfer pengetahuan (dengan salah satu indikator jumlah mahasiswa yang mendapatkan nilai (B), dan tanggung jawab (dengan indikator jumlah tatap muka di kelas dan ketepatan waktu menyerahkan nilai). Kinerja ini dapat dinilai langsung oleh mahasiswa.

Untuk setiap indikator yang telah ditetapkan, ditentukan target capaian mutu masing-masing. Target capaian mutu indikator misalnya $>90 \%$ dosen yang hadir mengajar 14 kali (tiap semester terdapat 14 tatap muka di kelas), >95\% dosen menyerahkan nilai tepat waktu (tiap pengiriman lembar jawaban disertai penetapan tanggal terakhir penyerahan nilai) dan $>90 \%$ dosen memperoleh nilai 3 (untuk skala 1 sampai 5) untuk penilaian mahasiswa terhadap kinerja dosen. Capaian target mutu terhadap masing-masing indikator akan menggambarkan tingkat kinerja jurusan atau prodi. Jika terjadi penyimpangan yang cukup besar terhadap capaian target mutu, misanya pada prodi tertentu hanya $75 \%$ dosen yang hadir mengajar 14 kali, hanya $80 \%$ dosen yang menyerahkan nilai tepat waktu dan hanya $80 \%$ dosen yang memperoleh nilai 3 dari penilaian mahasiswa, sedangkan pada prodi lain ada yang semua indikator capaian mutunya tercapai, ada yang hanya sebagian tercapai. Jika target capaian mutu dianalogikan dengan sebagai demand hasil prediksi dan capaian riil masing-masing indikator dianalogikan dengan demand yang terealisir, maka secara konseptual terjadi tidaknya BE dapat diukur. Apakah dengan demikian dapat terjadi BE pada tata kelola PT. Jawaban dari pertanyaan tersebut tidak mudah namun bagaimanapun usaha untuk mencari jawaban sangat perlu.

Penetapan program-program berserta capaian mutu indikatornya yang akan dilaksanakan selama setahun di tingkat prodi maupun fakultas telah didiskusikan secara mendalam dan telah disesuaikan dengan kondisi awal pada saat program diputuskan. Misalnya diprogramkan metode pengajaran tertentu untuk meningkatkan penilaian mahasiswa terhadap kineja dosen. Ternyata justru penilaian mahasiswa terhadap kinerja dosen rendah. Hal ini menunjukkan bahwa data awal kebutuhan konsumen yang digunakan untuk menyusun program tidak tepat. Jika mendasarkan pada pengertian ini, maka terjadinya fenomena sejenis BE pada tata kelola PT bukan merupakan kemustahilan. Namun demikian capaian mutu indikator tidak hanya disebabkan satu faktor saja, tetapi banyak faktor. Oleh karena itu sangat sulit untuk menjustifikasi dapat terjadi BE pada struktur tata kelola PT.

Memperhatikan lima faktor utama penyebab terjadinya BE pada business supply chain industri manufaktur, maka secara analogis dapat dijelaskan faktor-faktor yang dapat menjadi penyebab fenomena sejenis BE pada struktur tata kelola PT. Setiap 
UNISIA, Vol. XXXI No. 69 September 2008

tahun PT menyusun program yang akan dilaksanakan setahun ke depan atau dalam jangka panjang dan ditetapkan capaian setiap tahunnya. Setiap program disusun antara lain berdasarkan pengalaman dan data masa lalu dan perkiraan situasi ke depan. Kesalahan dalam mengidentifikasi kondisi yang akan terjadi setahun ke depan (forecasting error) dan ketidaktepatan dalam mengidentifikasi akar permasalahan yang sesungguhnya dari data dan pengalaman masa lalu merupakan faktor yang dapat menyebabkan terjadinya fenomena sejenis BE pada struktur tata kelola PT karena formulasi program dan target capaian mutunya menjadi tidak tepat.

Waktu antara formulasi dan pelaksanaan program umumnya tidak bersamaan. Formulasi program terjadi terlebih dahulu sebelum dilaksanakan. Semakin lama tenggang waktu (lead time) antara formulasi program dengan pelaksanaan program dapat menyebabkan pemahaman terhadap esensi program menjadi kurang tepat. Selain disebabkan oleh munculnya informasi-informasi baru, juga dapat disebabkan oleh menjadi kurang fokusnya pelaksana program.

Penetapan target capaian mutu setiap indikator program, tentu didasarkan pada data pelaksanaan program masa lalu dan estimasi kemampuan sistem dalam melaksanakan program yang telah diformulasikan. Kesalahan dalam menganalisis data masa lalu dan estimasi kemampuan sistem dalam melaksanakan program menyebabkan target capaian mutu menjadi over estimate atau under estimate (order batching dan supply shortages). Dan terakhir, kondisi lingkungan eksternal maupun internal yang tidak pasti (price fluctuations), dapat menyebabkan terjadi target capaian mutu program mungkin direvisi. Dengan demikian terlihat jelas bahwa kelima faktor penyebab terjadinya BE pada business supply chain industri manufaktur, juga merupakan penyebab terjadinya fenomena sejenis BE pada struktur tata kelola PT walaupun dengan definisi yang relatif berbeda.

\section{Penutup}

Bullwhip effect (BE) merupakan fenomena bertambahnya variansi kuantitas demand ketika bergerak upstream sepanjang supply chain industri manufaktur. Dari hasil kajian yang dilakukan pada bagian sebelumnya, ditemukan bahwa untuk hal-hal yang spesifik pada struktur tata kelola PT dimungkinkan terjadi fenomena yang sejenis BE. Oleh karena itu fenomena BE dapat dijadikan salah satu alternatif informasi dalam memperkaya pengelolaan PT.

Selain itu hal tersebut di atas, juga ditemukan bahwa kelima faktor utama penyebab terjadinya $\mathrm{BE}$, juga merupakan faktor penyebab dapat terjadinya fenomena sejenis pada struktur tata kelola PT, walaupun dengan definisi yang relatif berbeda.

\section{Daftar Pustaka}

Agrawal, S., Sengupta, S.N. dan Shanker, K., 2007, Impact of information saring and lead time on bullwhip effect and on-hand inventory, European Journal of Operational Research xxx, p. xxx$\mathrm{xxx}$

Dahri, I. dan Chabhoub, H., 2007., Nonlinier goal progamming models quatifying the bullwip effect in supply chains based on ARIMA parameters, European Journal of Operational Research 177, p. 1800-1810 
Fenomena Bullwhip Effect pada...; Farham HM. Saleh

Fransoo, J.C. dan Wouters, M.J.F., 2000, Measuring the bullwhip effect in supply chains managements, An International Journal 5 No. 2 p. 78-89

Gaspersz, V., 1997., Manajemen Kualitas Dalam Industri Jasa, Cetakan Pertama, PT. Gramedia Pustaka Utama, Jakarta

Hsieh, K.L., Chen, Y.K. dan Shen, C.C., 2007., Bootstrap confidence interval estimates of the bullwhip effect, European Journal of Operational Research 15, p. 908-917

Luong, H.T., 2007., Measure of bullwhip effect in supply chains with autoregresive demand process, European Journal of Operational Research 180, p. 1086-1097

Luong, H.T. dan Phien, N.H., 2007., Measure of bullwhip effect in supply chains: The case of high order autoregressive demand process, European Journal of Operational Research 183, p. 197-209

Ozelkan, E.T. dan Cakanyildrin, M., 2007., Reverse Bullwhip Effect in Pricing, European Journal of Operational Research $\mathrm{xxx}, \mathrm{p} . \mathrm{xxx}-\mathrm{x} \mathrm{xx}$

Ouyang, Y., 2007., The effect of information sharing on supply chains stability and the bullwhip effect, European Journal of Operational Research 182, p. 11071121

Ouyang, Y. dan Daganzo, C., 2008., Robust tests for the bullwhip effect in supply chains with stochastic dynamics, European Journal of Operational Research 185, p. 340-353

Zabidi, Y., 2003, Merancang dan Mengelola Supply Chain secara Efektif dan Efisien, Proceeding Seminar Nasional TEKNOIN, UII Yogyakarta 